\title{
Survei Penerapan Model Machine Learning Dalam Bidang Keamanan Informasi
}

\author{
Arif Rachmat \\ School of Electrical Engineering and Informatics \\ Institut Teknologi Bandung \\ Bandung, Indonesia \\ a@iainpalu.ac.id
}

\begin{abstract}
This paper provides a survey that discusses the spread used of machine learning models and algorithm for problems in information security. The breadth of the various types of techniques and methods by machine learning on this survey also figured by given examples of each model in the application for problems related to information security. The results of the study can be concluded that the use of machine learning in information security has spread widely in its use. Some methods are published in standard ways, with expectations this paper will give the insight to develop better models of machine learning applications in information security.
\end{abstract}

Keywords-information security, machine learning, model, algorithm.

Article history:

Received: 22 March 2019 Received in revised form: 27 March 2019 Accepted: 22 April 2019 Available online: April 2019

\section{Pendahuluan}

Dalam penelitian ilmu komputer machine learning merupakan salah satu kajian utama yang sedang populer saat ini, dan penelitian tersebut telah berdampak pada penerapan dalam banyak aplikasi. Dalam bidang keamanan informasi, masih belum banyak tersedia aplikasi potensial untuk machine learning.

Dalam survei ini, akan memperlihatkan berbagai macam teknik pemodelan dari algoritma yang digunakan dalam machine learning. Untuk setiap metode yang dibahas, dalam tulisan ini akan memberikan tinjauan umum, diikuti oleh contoh yang dapat menggambarkan aplikasi terkait keamanan informasi, yang di mana metode yang digunakan dapat terbukti bermanfaat. Informasi yang disajikan di sini dimaksudkan untuk memberikan gambaran secara ringkas, dan untuk memberikan wawasan tentang bagaimana penerapan berbagai aplikasi yang di mana pemodelan dan algoritma machine learning dapat memberikan manfaat lebih baik pada kemanan informasi.

Signifikansi melaksanakan penelitian ini adalah untuk memberikan informasi terkini kepada para peneliti bidang keamanan informasi bahwa bidang machine learning dan kecerdasan buatan dapat memberikan peluang yang lebih baik dalam melakukan analisa lebih cepat dan tepat dalam mendeteksi malware dan network intrusion.

Pada bagian II. Metodologi Penelitian akan dibahas bagaimana tulisan ini dapat dirangkum dengan menggunakan pendekatan metodologi systematic literature review $(S L R)$. Untuk lebih memahami lebih mendalam mengenai tulisan dan makalah terkait penelitian machine learning pada area keamanan informasi yang telah ada sebelumnya, maka tulisan ini melakukan $S R L$ yang mana $S L R$ merupakan sebuah studi sekunder untuk mengmpulkan penelitian yang berhubungan dengan penelitian utama. SLR diharapkan dapat membantu dalam menemukan solusi tentang penelitian sebelumnya. Tujuan utamanya dalam tulisan ini adalah untuk merangkum model algoritma machine learning yang digunakan sekaligus contoh penerapan aplikasi yang telah berjalan. Pemahaman ini dapat digunakan selanjutnya untuk mengembangkan penelitian selanjutnya. Untuk mendapatkan hasil komprehensif, maka area pencarian penelitian dilakukan pada mesin 
pencarian Google dengan menerapkan string query tertentu tanpa batasan tahun publikasi. Disamping itu pencarian juga dilakukan khusus pada dua database penelitian terbesar dalam bidang ilmu komputer yakni IEEE Xplore dan ACM dengan membatasi tahun terbitan makalah mulai tahun 2015 hingga 2019.

Pada bagian selanjutnya yakni bagian III. Hasil Survei, akan ditampilkan hasil yang relevan dari studi literatur yang dihasilkan dan pada bagian IV. Analisi, tulisan ini akan membuat analisis dari hasil survi, kemudian pada bagian V. Kesimpulan, tulisan ini akan memberikan pendapat kesimpulan dari keseluruhan hasil penelitian ini dan saran penelitian yang dapat dilakukan kedepan.

\section{Metodologi Penelitian}

\section{A. Tinjauan Literatur Sistematis (Systematic Literature Review)}

Tinjauan literatur sistematis $(S L R)$ adalah studi sekunder untuk memetakan, mengidentifikasi, mengevaluasi secara kritis, mengkonsolidasikan dan mengumpulkan hasil studi utama, yang relevan pada topik penelitian tertentu [1] [2] . SLR menjadi metode standar untuk mendapatkan jawaban dengan melakukan tinjauan pustaka berdasarkan studi terkait sebelumnya.

Tinjauan literatur pada penelitian ini adalah untuk lebih memahami jenis model algoritma dan jenis aplikasi dalam pendekatan metode yang menggunakan penerapan machine learning. Untuk mendapatkan hasil yang komprehensif, pada makalah ini dilakukan penelitian pada mesin pencari Google search dengan mengambil temuan pencarian 50 hasil pertama tanpa mempedulikan tahun publikasi, serta jenis makalah. Pencarian juga dilakukan pada dua database literatur online yang populer di bidang ilmu komputer, yakni IEEE Explore dan Association for Computing Machinery (ACM) digital library mulai dari tahun 2017 sampai 2019.

$S L R$ melakukan proses identifikasi, evaluasi dan interpretasi terhadap hasil pencarian yang sekiranya dapat menjawab pertanyaan penelitian (research question $/ R Q$ ). SLR terdiri dari beberapa tahapan yang secara komprehensif dapat digambarkan dalam urutan proses penyaringan informasi. SLR juga sebagai sarana pendekatan terstruktur dan sistematis dalam mengidentifikasi, memilih dan mensintesis literatur terbaru yang relevan dengan $R Q$ yang telah didefinisikan.

\section{B. Pertanyaan penelitian (Research Question)}

Tujuan dari pertanyaan penelitian $(R Q)$ adalah untuk mempertahankan fokus terhadap tinjauan literatur. Hal ini agar lebih mengarahkan penelitian ini terhadap proses pengambilan data yang relevan terhadap kebutuhan penelitian. Pada Tabel 1. menggambarkan pertanyaan penelitian pada penelitian ini.

Tabel 1.

Pertanyaan Penelitian

\begin{tabular}{lll}
\hline Id & Pertanyaan Penelitian & Motivasi \\
\hline RQ1 & $\begin{array}{l}\text { Model algoritma machine learning apa yang } \\
\text { digunakan? }\end{array}$ & $\begin{array}{l}\text { Melakukan identifikasi model algoritma } \\
\text { primer apa yang digunakan }\end{array}$ \\
\hline RQ2 & Apa sajakah aplikasi yang terkait? & $\begin{array}{l}\text { Melakukan identifikasi terhadap aplikasi } \\
\text { yang menerapkan model algoritma yang } \\
\text { digunakan }\end{array}$ \\
\hline
\end{tabular}




\section{Temuan Penelitian}

Agar dapat menjawab pertanyaan penelitian yang telah didefinisikan diatas, maka penelitian ini melakukan pencarian pada makalah penelitian yang diterbitkan pa da database pustaka jurnal populer dengan kata kunci spesifik untuk pencarian, dimulai pada tanggal 28 Maret 2019 hingga tanggal 31 Maret 2019. Kata kunci tersebut adalah " (machine AND learning AND (model OR algorithm)) AND information security". Tabel 2. menampilkan hasil pada pencarian tersebut.

Tabel 2.

Hasil Pencarian.

\begin{tabular}{clc}
\hline Index & \multicolumn{1}{c}{ Database Jurnal } & Jumlah Makalah \\
\hline 1 & IEEE Explore & 777 \\
\hline 2 & ACM Digital Library & 2.858 \\
\hline 3 & Google Search & 50 \\
\hline & Total & 3.685 \\
\hline
\end{tabular}

Pada penelitian ini menerapkan beberapa insklusi dan eksklusi, dengan harapan hasil pencarian fokus pada hasil yang relevan yang berhubungan secara langsung. Tabel 3 . memperlihatkan kriteria yang telah ditetapkan sebagai inklusi dan eksklusi.

Tabel 3 .

Kriteria Inklusi dan Eksklusi

\begin{tabular}{ll}
\hline \multicolumn{1}{c}{ Kriteria } \\
\hline Inklusi & I1 : Makalah berbentuk jurnal, majalah atau terbitan berkala kecuali hasil \\
pencarian Google search & I2: Pada abstrak tergambarkan metode atau model algoritma yang \\
digunakan dan contoh penerapan \\
I3 : Makalah ditulis dalam bahasa inggris \\
I4 : Makalah dapat diakses secara penuh tanpa batasan \\
\hline Eksklusi \\
E2: Makalah dengan pembahasan sejenis dalam database jurnal berbeda \\
\end{tabular}

Pada Figure 1. menampilkan proses penyaringan berdasarkan kriteria inklusi dan eksklusi, yang penyaringan tersebut dalam tulisan ini melihat terhadap judul dan metadata, abstrak, authorized access, dan akses penuh terhadap makalah.

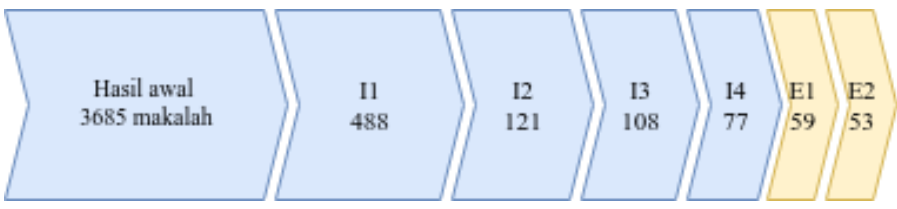

Figure 1. Proses Filtering Makalah

Dari hasil awal pencarian yang memberikan 3.685 hasil, kemudian dilakukan pemfilteran inklusi pertama, yakni kriteria I1 diterapkan kriteria tersebut berupa aturan hasil pencarian makalah harus berbentuk jurnal, majalah atau terbitan berkala untuk hasil pencarian yang bersumber dari IEEE Explore dan ACM digital library, namun tidak diberlakukan untuk hasil pencarian dari Google search, dan hasilnya terdapat 488 judul makalah lolos saringan. Kemudian dilakukan pemfilteran $\mathbf{I} 2$ yakni membaca cepat terhadap abstrak yang mengharuskan tergambarkan metode atau model algoritma atau contoh terapan aplikasi. Dari penyaringan ini dihasilkan 121 makalah yang ditetapkan lolos ke pemfilteran berikutnya. Kemudian dilakukan penyaringan $\mathbf{I 3}$ makalah yang harus full berbahasa inggris, dan kemudian menghasilkan 108 makalah, kemudian dilanjutkan 
pemfilteran I4 yakni makalah harus dapat diakses secara penuh tanpa batasan, yang menghasilkan 77 makalah.

Langkah selanjutnya melakukan pemfilteran ekslusi yang pertama yakni hasil pencarian yang sama akan diabaikan dari sumber pencarian berbeda $\mathbf{E} 1$, yang kemudian memberikan hasil pencarian yang unik sejumlah 59 makalah. Selanjutnya pemfilteran terakhir E2 dilakukan dengan membaca makalah secara komprehensif. Pada makalah yang tidak terkait langsung terhadap keamanan informasi akan diabaikan disini, dan pada proses terakhir ini menghasilkan makalah sejumlah 53 buah.

Setelah menerapkan kriteria inklusi dan eksklusi di atas, beberapa artikel yang diterbitkan dalam jurnal berkala atau proses konferensi, kemudian dilakukan pemeringkatan berdasarkan rangking scopus pada jurnal dan melakukan rekap terhadap prosiding hasil konferensi. Proses rekap juga melihat kepada hasil pencarian yang berupa thesis, whitepaper dan makalah lainnya untuk memenuhi kriteria dan dapat digunakan sebagai referensi utama untuk SLR.

Tabel 4.

Jenis Publikasi.

\begin{tabular}{|c|c|c|}
\hline Index & Jenis & Jumlah \\
\hline 1 & Buku & 7 \\
\hline 2 & Makalah & 5 \\
\hline 3 & Jurnal berkala Q1 & 9 \\
\hline 4 & Jurnal berkala Q2 & 5 \\
\hline 5 & Jurnal berkala Q3 & 0 \\
\hline 6 & Jurnal berkala Q4 & 1 \\
\hline 7 & Jurnal & 7 \\
\hline 8 & Proceeding & 18 \\
\hline \multirow[t]{2}{*}{9} & Thesis & 1 \\
\hline & Total & 53 \\
\hline
\end{tabular}


Pada Tabel 4. menunjukkan hasil proses perekapan dan rangking, sedangkan media publikasi dari masing-masing makalah ilmiah ditampilkan pada Tabel 5.

Tabel 5 .

Media Publikasi.

\begin{tabular}{|c|c|c|}
\hline Index & Jenis & Jumlah \\
\hline 1 & AAAI & 1 \\
\hline 2 & $\mathrm{ACM}$ & 4 \\
\hline 3 & ACM Computing Surveys & 1 \\
\hline 4 & BMC Bioinformatics & 1 \\
\hline 5 & British Machine Vision Conference & 1 \\
\hline 6 & Cambridge university & 1 \\
\hline 7 & Computers and Security & 1 \\
\hline 8 & CRC Press & 1 \\
\hline 9 & Elsevier & 1 \\
\hline 10 & Freie Universitat Berlin & 1 \\
\hline 11 & HSE University & 1 \\
\hline 12 & IEEE & 10 \\
\hline 13 & IEEE Transactions on Image Processing & 2 \\
\hline 14 & IEEE Transactions on Neural Networks & 1 \\
\hline 15 & IEEE Transactions on Systems, Man and Cybernetics & 1 \\
\hline 16 & Information Sciences & 1 \\
\hline 17 & Institute For Signal And Information Processing Linear & 1 \\
\hline 18 & Journal in Computer Virology & 1 \\
\hline 19 & Journal of Computer Security & 1 \\
\hline 20 & Journal of Computer Virology and Hacking Techniques & 4 \\
\hline 21 & Journal of the American Statistical Association & 1 \\
\hline 22 & Nara Institute of Science and Technology & 1 \\
\hline 23 & National Science Foundation & 1 \\
\hline 24 & Princeton university & 2 \\
\hline 25 & R Journal & 1 \\
\hline 26 & San Jose University & 1 \\
\hline 27 & Springer & 6 \\
\hline 28 & The University of Alabama at Birmingham & 1 \\
\hline 29 & USENIX Symposium & 1 \\
\hline \multirow[t]{2}{*}{30} & Unknown & 2 \\
\hline & Total & 53 \\
\hline
\end{tabular}

\section{HaSil SURVEY}

\section{A. Hidden Markov Model (HMM)}

Beberapa tinjauan mengenai model $H M M$ dibahas pada tutorial beberapa penulis [3] . Seperti namanya model markov memiliki rantai yang tersembunyi yang tidak dapat diamati secara langsung, Figure 2. memperlihatkan garis putus-putus sebagai tirai yang menghalangi untuk dapat dipantau secara langsung. 


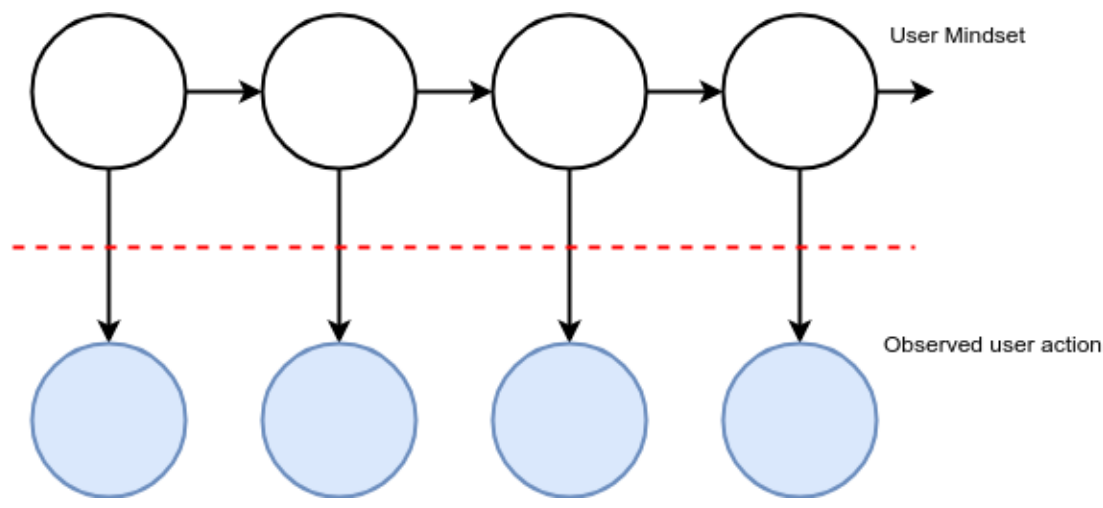

Figure 2. Hidden Markov Model

Dengan menggunakan $H M M$, terdapat beberapa keunggulan diantaranya karena bersifat probabilistik, maka kita dapat memperoleh informasi yang berguna pada prosesnya. Aplikasi yang terkait dengan $H M M$ digunakan secara luas dalam ilmu komputer, dan sebagai contoh dalam keamanan informasi telah diterapkan pada analisis malware [3] [4] . Diawal kemunculannya, malware dapat dikenali dengan baik melalui pattern khas pada kode binari tubuh malware, kemudian dalam perjalannya malware bermetamorfosis untuk menghindari deteksi ciri khas pada tubuh malware. HMM berhasil diimplementasikan oleh perusahaan antivirus untuk mendeteksi perubahan struktur internal malware setelah menjangkit [5] . Selain itu $H M M$ juga dimanfaatkan dalam sistem pendeteksi serangan (intrusion detection system/IDS) [6] [7] .

\section{B. Support Vector Machines (SVM)}

SVM merupakan salah satu model algoritma yang populer dalam machine learning. Dengan konsep sederhana namun untuk dapat dipahami secara mandalam bisa sangat sulit karena karakteristiknya. Dari sudut pandang secara komprehensif, $S V M$ mempunyai ciri berusaha memberikan jarak maksimum class pada data menggunakan istilah hyperplane, dengan memaksimalkan jarak antar kelas, yang dapat diilustrasikan pada Figure 3. Trik kernel diterapkan pada $S V M$ untuk meningkatkan jarak antar class dengan tanpa memberikan beban komputasi yang tinggi. Meskipun usaha trik kernel tidaklah mudah namun memberikan hasil yang memuaskan [8] [9] .

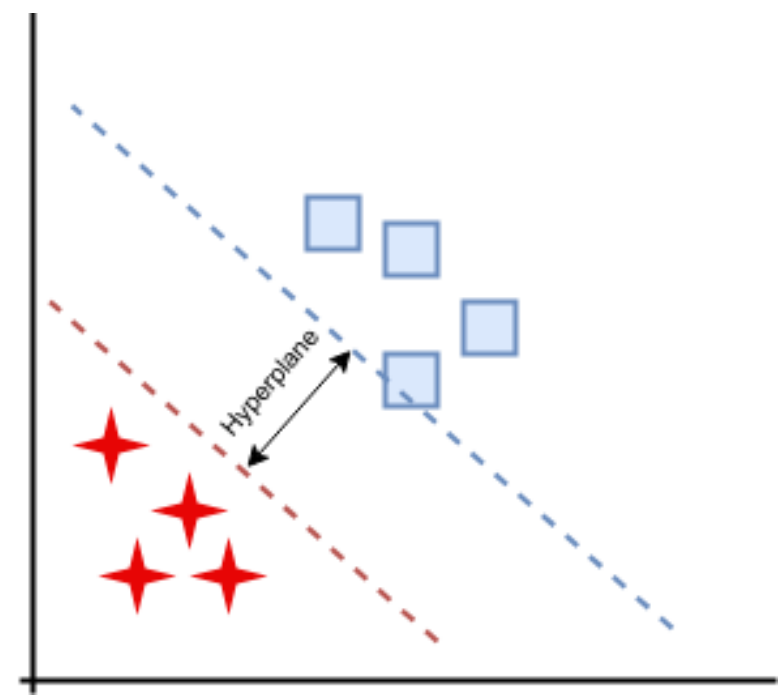

Figure 3. Ilusttrasi model SVM dengan memaksimalkan jarak 
Dalam aplikasinya, $S V M$ menjadi salah satu model yang terbaik dalam mendeteksi malware [10] [11] , yang ditunjukan dalam hasil skor penilaian malware yang berusaha melakukan perubahan bentuk, dapat dengan baik di deteksi perubahannya oleh model $S V M$ [12] . SVM juga diaplikasikan dalam menganalisis gambar spam pada email [13] [14] dan juga menganalisis spam berdasarkan teks [15] , serta pada intrusion detection systems sistem [16] [17] [18] , analisis serangan terhadap jaringan [19] .

\section{Clustering}

Dalam melakukan pengelompokan data, terkadang data yang ingin dikelompokan belum memiliki label khusus, dan para peneliti menginginkan agar mesin dapat melakukan pengelompokan tersebut berdasarkan karakteristik kemiripan data yang dimiliki. Dalam prosesnya teknik clustering melakukan eksplorasi data yang berupaya mendapatkan insight terhadap nilai data yang anomali. Pada awal penelitian clustering, terdapat beberapa makalah lawas yang telah membahasnya [20] [21] . Penerapan metode clustering yang populer salah satunya adalah $K$-Means, prinsip kerjanya adalah melakukan proses berulang untuk menghitung nilai tengah dari masing-masing edge, kemudian mengelompokannya berdasarkan nilai kedekatan paling mirip. Dalam pengelompokannya merujuk terhadap pemberian nilai K yang telah didefinisikan. Metode clustering lainnya yakni Expectation maximization (EM), dengan prosedur yang mirip K-Means, tetapi dalam menetapkan pengelompokan meng gunakan probabilitas terdistribusi gaussian dapat dilihat pada Figure 4. dengan ciri khas pengelompokan berbentuk elips, sementara untuk metode lainnya terkadang tidak beraturan.

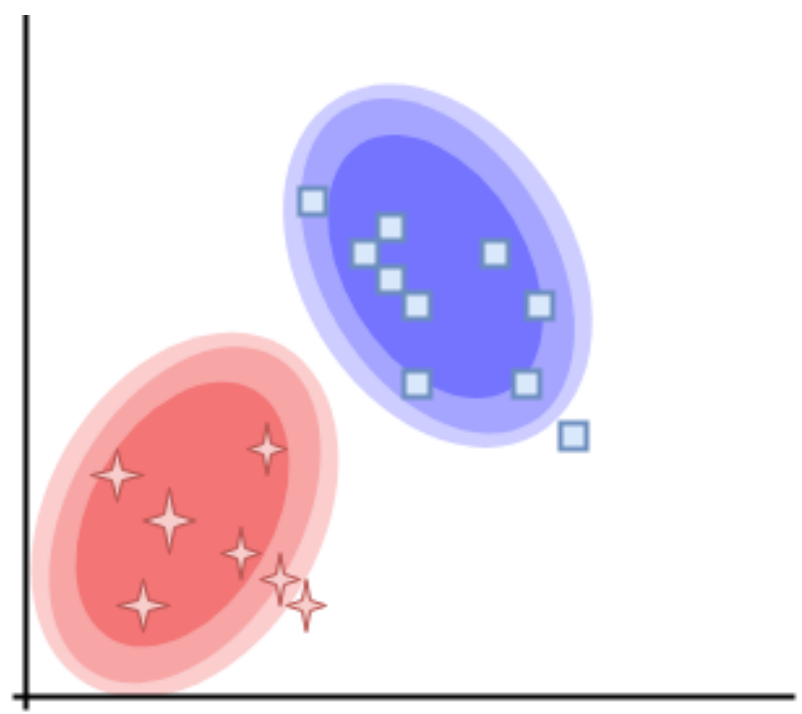

Figure 4. Ilusttrasi clustering dengan metode EM

Model clustering telah diteliti dan diterapkan secara luas, yang khusus fokus dalam keamanan informasi sebagai contoh dalam melakukan deteksi, analisis dan klasifikasi terhadap malware. Pada percobaan clustering malware telah dilakukan oleh beberapa penelitian [22] [23] [24] . Berbagai jenis clustering juga telah diterapkan pada berbagai masalah kemanan informasi lainnya termasuk deteksi spam [25] , dan serangan terhadap jaringan [26] , serta telah dibuktikan dapat melakukan mendeteksi serangan penyusup dalam jaringan [27] , deteksi botnet dalam aktifitas jaringan [28] , serta berbagai isu pelanggaran privasi [29] serta banyak aplikasi lainnya. 


\section{Linear Discriminant Analysis}

Linear Discriminant Analysis (LDA) dibangun berdasarkan pengembangan metode principal component analysis (PCA) dan SVM, akan tampak bahwa PCA dan SVM memiliki beberpa kemiripan satu sama lain. Namun pada $L D A$ memberikan informasi "missing link" yang menghubungkan diantara $P C A$ dan $S V M$, dan untuk alasan inilah penelitian $L D A$ menjadi menarik untuk diteliti lebih jauh. Untuk informasi lebih lanjut tentang $L D A$ beberapa makalah telah membahasnya dengan baik [30] [29] dalam menambah insight mengenai metode $L D A$. Untuk mengilustrasikan proses proyeksi $L D A$, perhatikan contoh-contoh yang muncul pada Figure 5. dan Figure 6. Pada Figure 5., terdapat proyeksi dalam dua kelas (lingkaran dan kotak) ke hyperplane di mana class tidak dipisahkan dengan baik. Sebaliknya, data yang diproyeksikan pada Figure 6. lebih baik dipisahkan. Dalam $L D A$, proyeksi data pelatihan ke hyperplane yang terbaik adalah dengan memisahkan set pelatihan, seperti contohnya dengan cara mendefinisikan pemisahan berdasarkan oleh ukuran yang menggabungkan pemisahan antara kelas dengan ukuran ideal nilai yang lebih besar atau lebih kecil.

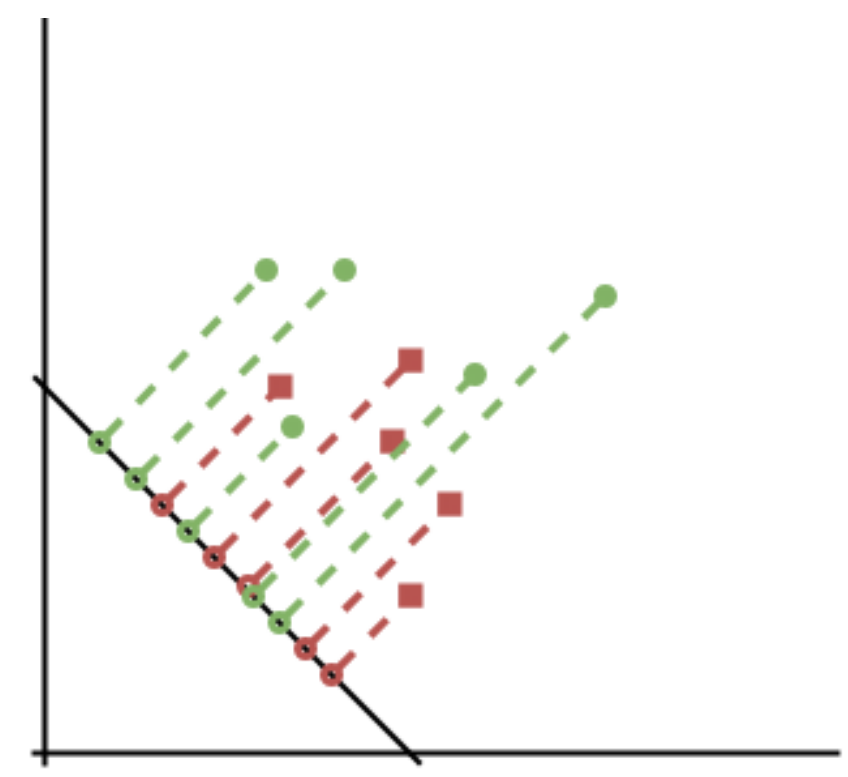

Figure 5. Ilusttrasi clustering dengan metode EM

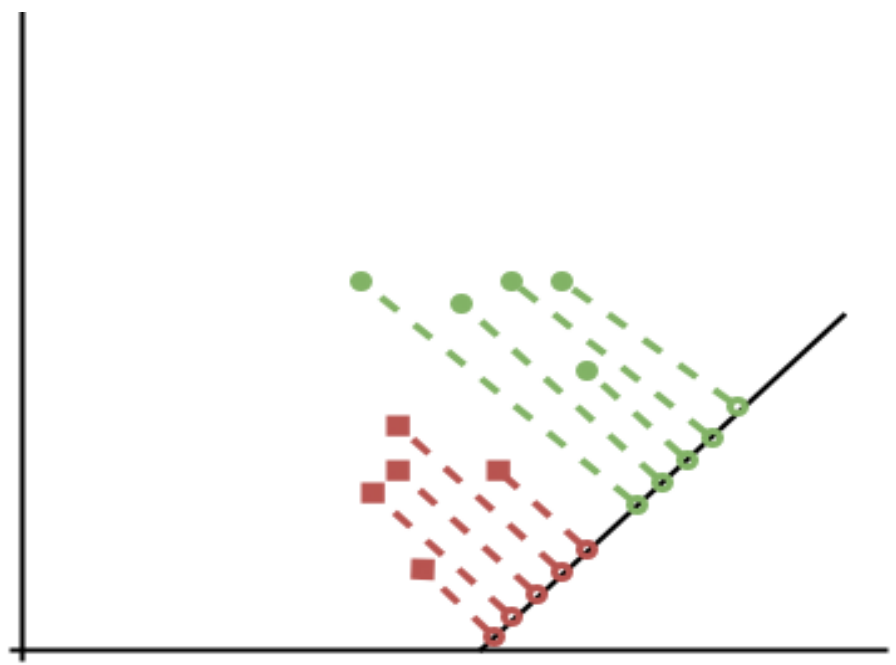

Figure 6. Ilusttrasi proyeksi LDA yang lebih baik 
Dalam aplikasinya, $L D A$ telah diterapkan dalam memecahkan permasalahan dalam pengenalan biometrik, termasuk didalamnya pengenalan wajah [31] [32] [33] dan pengenalan cara berjalan [34].

\section{E. K-Nearest Neighbor}

K-Nearest Neighbor $(k-N N)$ adalah salah satu metode dalm membangun model pengelompokan dalam machine learning yang relatif mudah dipahami, sebab pengelompokan data dilakukan dengan hanya melihat tetangga terdekat dari sebuah dataset. Dalam $k-N N$, tidak terdapat fase eksplisit yang dilakukan, karena jika pelabelan dalam dataset telah ditentukan maka model tidak dapat lagi dilatih, beberapa makalah berikut menjelaskan tentang hal tersebut [35] . Dalam aplikasinya teknik $k-N N$ digunakan secara luas di berbagai penerapan seperti contohnya intrusion detection [36] , otentikasi dasar biometrik dalam keystroke dynamics [37] dan mengamankan query dalam teknologi cloud [38].

\section{F. Random Forest}

Random forest $(R F)$ merupakan salah satu metode pemodelan machine learning paling populer, dimana prinsip kerjanya berdasarkan decision tree, oleh sebab itu relatif mudah dipahami. Desicion tree memiliki struktur data lebih sederhana untuk dibangun, bersifat intuitif dan mudah digabungkan dengan metode-metode lainya. Kekurangan utama decision tree adalah bahwa cenderung akan menyesuaikan data pelatihan yang biasanya tidak diinginkan untuk suatu algoritma machine learning.

Dalam mengilustrasikan decision tree, semisal kita telah memiliki dataset yang telah memiliki diberi label malware dan bukan malware, kemudian dilakukan training terhadap data, hasil pengamatan menunjukkan bahwa contoh data malware cenderung memiliki ukuran lebih kecil namun memilikin nilai entropi lebih tinggi dibanding yang bukan malware. Maka kita dapat menggunakan informasi tersebut menjadi salah satu parameter dalam membangun rule decision tree, dapat dilihat pada Figure 7., dimana jarak ambang batas untuk nilai besar dibandingkan dengan nilai kecil serta entropi rendah dibandingkan dengan entropi tinggi akan menjadi dasar aturan pada data latih. Desicion tree ini kemudian dapat digunakan untuk mengklasifikasikan data uji sebagai malware atau bukan berdasarkan nilai entropinya. Kebalikan dari Figure 7., dapat dilihat pada Figure 8.

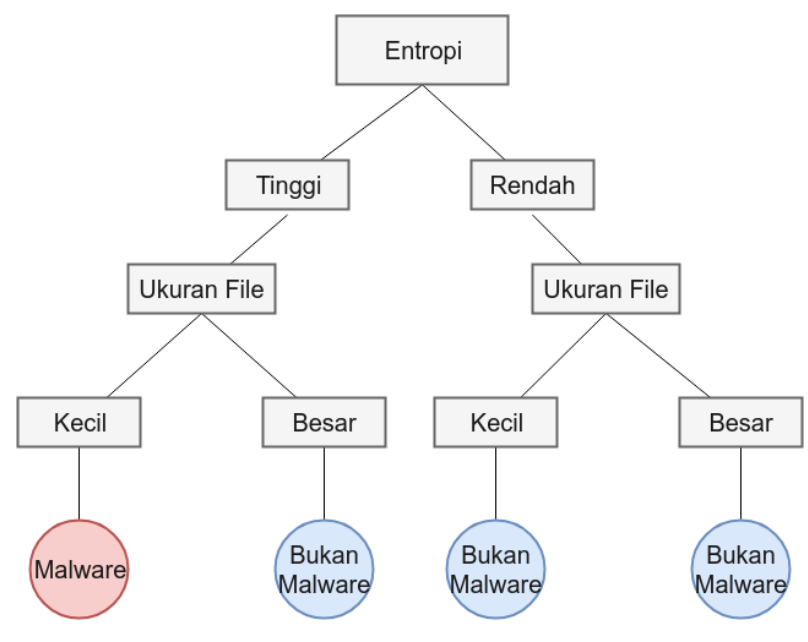

Figure 7. Contoh ilustrasi decision tree pada random forest 


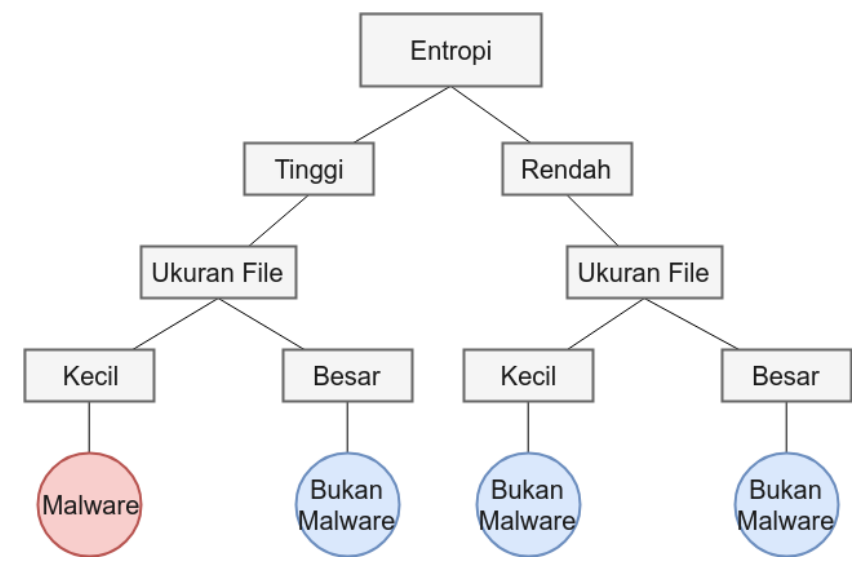

Figure 8. Contoh ilustrasi decision tree pada random forest dengan fitur berbeda

Terlihat pada Figure 7. contoh data dengan ukuran "large" akan selalu diklasifikasikan sebagai bukan malware dengan tanpa melihat entropi, sedangkan pada Figure 8. dengan nilai entropi rendah akan selalu diklasifikasikan sebagai bukan malware. Secara umum semakin dekat ke root decision maka akan cenderung berpengaruh terhadap klasifikasi akhir.

Dalam konteks decision tree, informasi yang dapat dihitung sebagai entropi diperoleh dari parent node dikurangi nilai rata-rata entropi child node. Pada saat membuat decision tree, maka akan dapat diukur informasi yang diperoleh dari setiap fitur yang ada, dan melakukan pemilihan secara greedy, yakni tanpa mempertimbangkan lagi nilai pada $\backslash$ node sebelumnya apakah lebih kecil atau tidak. Dengan cara seperti ini maka fitur dengan perolehan nilai tertinggi akan paling dekat dengan root. Hal ini diharapkan untuk mengurangi perhitungan entropi. Manfaat lainnya adalah kita dapat m enyederhanakan tree dengan memangkas fitur-fitur yang tidak berpengaruh signifikan terhadap hasil.

Untuk menghindari kecenderungan model dari decision tree yang terlalu overfit terhadap data, maka teknik "bagging" dapat diimplementasikan. Bagging dapat konsisten dalam memilih (overlapping) data latih, dan membangun decision tree pada setiap sub set. Kemudian dapat dengan baik memperoleh klasifikasi secara keseluruhan, sebagai contoh menggunakan voting dalam bagged decision tree. Dalam random forest konsep bagging diterapkan secara umum lebih lanjut untuk menyimpan ninlai fitur dan data, penelitian tentang random forest terdapat pada mekalah berikut [39] [40] .

Random forest telah diimplementasikan secara ekstensif untuk memecahkan masalah keamanan informasi, termasuk didalamnya permasalahan intrusion detection system [41] [42] , deteksi malware [43] [44] pemalsuan PDF [45], pengenalan wajah [46], deteksi celah kemanan software [47], dan lainnya.

\section{G. Boosting}

Boosting merupakan salah satu teknik dalam menggabungkan beberapa metode pengklasifikasian yang lemah dan cenderung menghasilkan error menjadi klasifikasi yang lebih baik [48] , dengan memberikan boost pada fitur yang dianggap lemah agar terhindar dari error tersebut. Terdapat banyak teknik machine learning yang dapat diterapkan sebagai contoh penggabungan skor $H M M$, skor $P C A$, dan skor $L D A$ dengan menggunakan SVM untuk membangun classifier [49] . 
Adaboost (adaptive boosting) adalah salah satu metode boosting terbaik yang digunakan dan secara luas diterapkan sebagai algoritma. Dalam setiap iterasi dari adaboost sifat greedy digunakan, dalam artian bahwa classifier dipilih secara manual untuk dikuatkan oleh adaboost. Ini merupakan pendekatan adaptif yang dilakukan dalam membangun classifier. Penerapan pada aplikasi yang menggunakan metode boosting telah terbukti berguna sebagai intrusion detection [50], deteksi phising [51], dan analisis malware [52] [53].

\section{Analisis}

Pemanfaatan model machine learning dalam membangun aplikasi keamanan informasi telah menjadi keharusan untuk saat ini. Para peneliti terus mengembangkan model dan algoritma serta melakukan optimalisasi dari sisi kemampuan analisis terhadap metodemetode terbaru serangan keamanan informasi dan pelanggaran terhadap data privasi pengguna.

Tabel 6.

Jenis Publikasi.

\begin{tabular}{clc}
\hline Index & \multicolumn{1}{c}{ Penerapan } & Model by Method \\
\hline 1 & Malware Analysis & $H M M, S V M$, Clustering, $R F$, Boosting \\
\hline 2 & Intrusion Detection System & $H M M, k-N N, R F$, Boosting \\
\hline 3 & Spam Analysis & $S V M$, Clustering, Boosting \\
\hline 4 & Network Analysis & $S V M$, Clustering \\
\hline 5 & Privacy Analysis & Clustering \\
\hline 6 & Biometric Analysis & $L D A, k-N N, R F$ \\
\hline 7 & Cloud Security & $k-N N$ \\
\hline 8 & Software Analysis & $R F$ \\
\hline
\end{tabular}

Dari tujuh metode yang menghasilkan model yang telah dibahas diatas, menghasilkan delapan kelompok fungsi aplikatif, yang terbukti mampu dengan baik dalam melakukan upaya preventif, prediktif, deteksi dan monitoring dalam keamanan informasi. Jika diurutkan dari aplikasi yang paling banyak digunakan yakni penganan malware, intrusion detection system, spam analysis dan biometric analysis, network analysis, privacy, cloud computing dan software analysis.

Beberapa sektor dalam kemanan informasi yang menjadi trend saat ini yakni tentang sistem terdistribusi dan informasi internet of things belum banyak disentuh dengan pengaplikasian model machine learning dalam melakukan upaya mengamankan transmisi data, hal ini yang kemudian dapat dilakukan penelitian lebih lanjut.

\section{Kesimpulan}

Dalam survei ini telah dibahas secara singkat metode-metode machine learning dalam menghasilkan model yakni $H M M, S V M, V Q, L D A, k-N N$, dan $R F$ serta terdapat juga teknik boosting. Dalam setiap kasus, dalam tulisan ini juga menyediakan contoh berbagai aplikasi keamanan informasi terkait, yang dimana secara teknis model machine learning yang dihasilkan terbukti bermanfaat. Sejumlah besar petunjuk untuk literatur yang relevan telah diberikan, termasuk referensi dan artikel pengantar lainnya tentang masing-masing dari berbagai metode. Untuk mempelajari lebih dalam topik yang dibahas di sini. 


\section{REFERENCES}

[1] A. Dresch, D. P. Lacerda, and J. A. V. Antunes, Design science research : a method for science and technology advancement. Springer.

[2] B. Kitchenham et al., "Systematic literature reviews in software engineering - A tertiary study," Inf. Softw. Technol., vol. 52, no. 8, pp. 792-805, Aug. 2010.

[3] M. Stamp, "A Revealing Introduction to Hidden Markov Models," no. October 2018,pp. 1-11, 2018.

[4] A. Kalbhor, T. H. Austin, E. Filiol, S. Josse, and M. Stamp, "Dueling hidden Markov models for virus analysis," J. Comput. Virol. Hacking Tech., vol. 11, no. 2, pp. 103-118, May 2015.

[5] W. Wong and M. Stamp, "Hunting for metamorphic engines," J. Comput. Virol., vol. 2, no. 3, pp. 211-229, Nov. 2006.

[6] T. Okamoto and Y. Ishida, "Framework of an Immunity-Based Anomaly Detection System for User Behavior," in Knowledge-Based Intelligent Information and Engineering Systems, Berlin, Heidelberg: Springer Berlin Heidelberg, 2007, pp. 821-829.

[7] R. Posadas, C. Mex-Perera, R. Monroy, and J. Nolazco-Flores, "Hybrid Method for Detecting Masqueraders Using Session Folding and Hidden Markov Models," Springer, Berlin, Heidelberg, 2006, pp. 622-631.

[8] N. Cristianini and J. Shawe-Taylor, An Introduction to Support Vector Machines and Other Kernel-based Learning Methods. Cambridge: Cambridge University Press, 2000.

[9] R. Berwick and V. Idiot, "An Idiot's guide to Support vector machines (SVMs)," 2003.

[10] I. Firdausi, C. lim, A. Erwin, and A. S. Nugroho, "Analysis of Machine learning Techniques Used in Behavior-Based Malware Detection," in 2010 Second International Conference on Advances in Computing, Control, and Telecommunication Technologies, 2010, pp. 201-203.

[11] Y. Ye, T. Li, D. Adjeroh, and S. S. Iyengar, "A Survey on Malware Detection Using Data Mining Techniques," ACM Comput. Surv., vol. 50, no. 3, pp. 1-40, Jun. 2017.

[12] K. Rieck, P. Trinius, C. Willems, and T. Holz, "Automatic Analysis of Malware Behavior using Machine Learning," J. ofComputer Secur., pp. 1-30, 2011.

[13] M. Kamble and C. Dule, "Image Spam Detection : A Review," 2017.

[14] A. Annadatha and M. Stamp, "Image spam analysis and detection," J. Comput. Virol. Hacking Tech., vol. 14, no. 1, pp. 39-52, Feb. 2018.

[15] H. Drucker, Donghui Wu, and V. N. Vapnik, "Support vector machines for spam categorization," IEEE Trans. Neural Networks, vol. 10, no. 5, pp. 1048-1054, 1999.

[16] W. Hu and W. Hu, "Robust Support Vector Machines for Anomaly Detection," PROC. 2003 Int. Conf. Mach. Learn. Appl. (ICMLA'03, pp. 23--24, 2003.

[17] S. Mukkamala, G. Janoski, and A. Sung, "Intrusion detection using neural networks and support vector machines," in Proceedings of the 2002 International Joint Conference on Neural Networks. IJCNN'02 (Cat. No.02CH37290), pp. 1702-1707.

[18] L. Khan, M. Awad, and B. Thuraisingham, "A new intrusion detection system using support vector machines and hierarchical clustering," $V L D B J$. , vol. 16, no. 4, pp. 507-521, Aug. 2007.

[19] T. Sohn, J. Seo, and J. Moon, “A Study on the Covert Channel Detection of TCP/IP Header Using Support Vector Machine," Springer, Berlin, Heidelberg, 2003, pp. 313-324.

[20] Kumar, "Cluster Analysis: Basic Concepts and Algorithms," Psychology.

[21] B. Mirkin, "Choosing the number of clusters," Wiley Interdiscip. Rev. Data Min. Knowl. Discov., vol. 1, no. 3, pp. 252-260, 2011. 
[22] U. Narra, F. Di Troia, V. A. Corrado, T. H. Austin, and M. Stamp, "Clustering versus SVM for malware detection," J. Comput. Virol. Hacking Tech., vol. 12, no. 4, pp. 213-224, Nov. 2016.

[23] J. Kinable and O. Kostakis, "Malware classification based on call graph clustering," J. Comput. Virol., vol. 7, no. 4, pp. 233-245, Nov. 2011.

[24] R. Perdisci, W. Lee, and N. Feamster, "Behavioral Clustering of HTTP-Based Malware and Signature Generation Using Malicious Network Traces," USENIX Symp. Networked Syst. Des. Implement. NSDI, pp. 26-26, 2010.

[25] C. Wei, A. Sprague, and G. Warner, "Clustering malware-generated spam emails with a novel fuzzy string matching algorithm," no. 205, p. 889, 2009.

[26] L. Portnoy, L. Portnoy, E. Eskin, and S. Stolfo, "Intrusion detection with unlabeled data using clustering," Proc. ACM CSS Work. DATA Min. Appl. TO Secur. (DMSA2001, pp. 5--8, 2001.

[27] and W. L. Guofei Gu1, Roberto Perdisci, Junjie Zhang, "BotMiner: Clustering Analysis of Network Traffic for Protocol- and Structure-Independent Botnet Detection Guofei," USENIX Secur. Symp., no. January 2008, pp. 139-154, 2008.

[28] J. Vaidya and C. Clifton, "Privacy-preserving $k$-means clustering over vertically partitioned data," in Proceedings of the ninth ACM SIGKDD international conference on Knowledge discovery and data mining - KDD '03, 2003, p. 206.

[29] S. Kaya, B. Cicioğlu Aridoğan, and M. Demirci, "Linear Discriminant Analysis - A Brief Tutorial," Mikrobiyol. Bul., vol. 38, no. 4, pp. 421-427, 2004.

[30] M. Sakai, N. Kitaoka, and S. Nakagawa, "Power linear discriminant analysis," 2007 9th Int. Symp. Signal Process. its Appl. ISSPA 2007, Proc., no. 2, 2007.

[31] M. Kan, S. Shan, D. Xu, and X. Chen, "Side-Information based Linear Discriminant Analysis for Face Recognition," in Procedings of the British Machine Vision Conference 2011, 2011, p. 125.1-125.0.

[32] Chengjun Liu and H. Wechsler, "Gabor feature based classification using the enhanced fisher linear discriminant model for face recognition," IEEE Trans. Image Process., vol. 11, no. 4, pp. 467-476, Apr. 2002.

[33] J. Lu, K. N. Plataniotis, and A. N. Venetsanopoulos, "Regularization studies of linear discriminant analysis in small sample size scenarios with application to face recognition," Pattern Recognit. Lett., vol. 26, no. 2, pp. 181-191, 2005.

[34] N. V. Boulgouris and Z. X. Chi, "Gait Recognition Using Radon Transform and Linear Discriminant Analysis," IEEE Trans. Image Process., vol. 16, no. 3, pp. 731-740, Mar. 2007.

[35] Z. Yao and W. L. Ruzzo, "A Regression-based K nearest neighbor algorithm for gene function prediction from heterogeneous data," BMC Bioinformatics, vol. 7, no. S1, p. S11, Mar. 2006.

[36] Y. Liao and V. R. Vemuri, "Use of K-Nearest Neighbor classifier for intrusion detection," Comput. Secur., vol. 21, no. 5, pp. 439-448, Oct. 2002.

[37] J. Hu, D. Gingrich, and A. Sentosa, "A k-Nearest Neighbor Approach for User Authentication through Biometric Keystroke Dynamics," in 2008 IEEE International Conference on Communications, 2008, pp. 1556-1560.

[38] Y. Elmehdwi, B. K. Samanthula, and W. Jiang, "Secure k-nearest neighbor query over encrypted data in outsourced environments," in 2014 IEEE 30th International Conference on Data Engineering, 2014, pp. 664-675.

[39] A. Liaw and M. Wiener, "Classification and Regression by randomForest," $R$ news, vol. 2, no. December, pp. 18-22, 2002.

[40] Y. Lin and Y. Jeon, "Random Forests and Adaptive Nearest Neighbors," Journal of the American Statistical Association, vol. 101. Taylor \& Francis, Ltd.American Statistical Association, pp. 578-590. 
[41] J. Zhang and M. Zulkernine, "A hybrid network intrusion detection technique using random forests," in First International Conference on Availability, Reliability and Security (ARES'06), 2006, p. 8 pp.-269.

[42] S. Thaseen and C. A. Kumar, "An analysis of supervised tree based classifiers for intrusion detection system," in 2013 International Conference on Pattern Recognition, Informatics and Mobile Engineering, 2013, pp. 294-299.

[43] B. Sanz, I. Santos, C. Laorden, X. Ugarte-Pedrero, P. G. Bringas, and G. Álvarez, "PUMA: Permission Usage to Detect Malware in Android," Springer, Berlin, Heidelberg, 2013, pp. 289-298.

[44] I. Santos, F. Brezo, X. Ugarte-Pedrero, and P. G. Bringas, "Opcode sequences as representation of executables for data-mining-based unknown malware detection," Inf. Sci. (Ny)., vol. 231, pp. 64-82, May 2013.

[45] C. Smutz and A. Stavrou, "Malicious PDF detection using metadata and structural features," in Proceedings of the 28th Annual Computer Security Applications Conference on - ACSAC '12, 2012, p. 239.

[46] V. Ghosal, P. Tikmani, and P. Gupta, "Face Classification Using Gabor Wavelets and Random Forest," in 2009 Canadian Conference on Computer and Robot Vision, 2009 , pp. 68-73.

[47] V. H. Nguyen and L. M. S. Tran, "Predicting vulnerable software components with dependency graphs," in Proceedings of the 6th International Workshop on Security Measurements and Metrics-MetriSec '10, 2010, p. 1.

[48] R. R. Rojas, "AdaBoost and the Super Bowl of Classifiers A Tutorial Introduction to Adaptive Boosting," Writing, pp. 1-6, 2009.

[49] M. Stamp, Introduction to machine learning with applications in information security. .

[50] Weiming $\mathrm{Hu}$, Wei Hu, and S. Maybank, "AdaBoost-Based Algorithm for Network Intrusion Detection," IEEE Trans. Syst. Man, Cybern. Part B, vol. 38, no. 2, pp. 577-583, Apr. 2008.

[51] D. Miyamoto, H. Hazeyama, and Y. Kadobayashi, "A Proposal of the AdaBoostBased Detection of Phishing Sites." 2007.

[52] A. M. Aswini and P. Vinod, "Droid permission miner: Mining prominent permissions for Android malware analysis," in The Fifth International Conference on the Applications of Digital Information and Web Technologies (ICADIWT 2014), 2014, pp. 81-86.

[53] M. S. Khan, S. Siddiqui, R. D. McLeod, K. Ferens, and W. Kinsner, "Fractal based adaptive boosting algorithm for cognitive detection of computer malware," in 2016 IEEE 15th International Conference on Cognitive Informatics \& Cognitive Computing (ICCI*CC), 2016, pp. 50-59. 